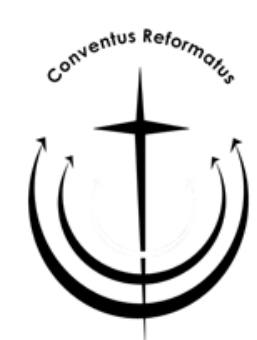

\title{
The influence of Calvinism on the South African Council of Churches
}

\author{
P.G.J. Meiring \\ Department of Science of Religion and Missiology \\ University of Pretoria \\ PRETORIA \\ E-mail: pietmeiring@telkomsa.net
}

\section{Abstract \\ The influence of Calvinism on the South African Council of Churches}

The impact of Calvinist theology and of reformed leadership on the South African Council of Churches (SACC) is vast. After a brief history of the SACC, the author notes the contribution that a number of reformed and presbyterian clergy and theologians have made - as presidents, general secretaries or as theologians who helped develop the SACC's message. At least five principles that Calvin held dear, are reflected in the SACC's agenda during the past decades: the quest for unity, the concern for mission, covenanting for justice, providing a prophetic witness in the community, and when the need arose, the willingness to confront the government of the day. The article concludes with a brief look at the future of the SACC and of the continued input that reformed theologians may be able to make.

\section{Opsomming}

\section{Die invloed van Calvinisme op die Suid-Afrikaanse Raad van Kerke}

Die invloed van die Calvinistiese teologie en van kerkleiers vanuit die gereformeerde tradisie op die Suid-Afrikaanse Raad van kerke (SARK) is groot. Na 'n kort oorsig oor die geskiedenis van die SARK bespreek die outeur die bydraes van 'n aantal gereformeerde en presbiteriaanse kerkleiers en teoloë - presidente, algemene sekretarisse en teologiese raadgewers, in hierdie verband. Ten minste vyf beginsels wat vir Calvyn belangrik was, word in die agenda van die SARK gedurende die afgelope dekades, gereflekteer: die soeke na eenheid, die belangrikheid van sending, die noodsaaklikheid van geregtigheid, 
die profetiese taak van die kerk in die samelewing, en indien die situasie dit vereis, die noodsaaklikheid om die owerheid oor hierdie sake te konfronteer. Die artikel word met 'n kort vooruitskouing afges/uit waarin die rol bespreek word wat die SARK en die gereformeede teoloë in sy midde in die toekoms sou kon speel.

\section{A brief history of the South African Council of Churches (SACC)}

Eighteen hundred years ago, the North African theologian Tertullian, confronted the church with the question: "What is there in common between Athens and Jerusalem?" In his mind, the answer was: "Nothing!" (Bettenson, 1950:7 ff.). I am asked to answer a similar riddle: What has Geneva and Johannesburg to do with one another, the Church of St. Pierre and Khotso House? In 2009, when the birth of John Calvin 500 years ago was celebrated, many questions were asked about the Swiss reformer's influence in the church, as well as in public life. My intention is to discuss the influence of Calvinism on the South African Council of Churches (SACC) - if, indeed, any such an influence can be established. As was the case with Tertullian's question, the answer to mine needs careful research and explanation.

What is the South African Council of Churches and what is its mission? Who were the individuals who accepted leadership roles in the organisation through the years?

\subsection{The roots of ecumenism in South Africa: the Christian Council of South Africa}

The roots of the SACC reach back to more than a century ago, when a number of protestant churches and mission organisations founded the South African General Missions Council (1904). The SAGMC was a dynamic organisation, and in the years that followed many conferences and workshops were held, well attended by delegates from the Anglican, Methodist, Presbyterian and Dutch Reformed Churches, together with colleagues from other churches and organisations (Geldenhuys, 1982:103). In May 1934 the well-known missionary leader John R. Mott, visited South Africa and after discussions with him it was decided that the time was ripe for the establishment of a more widely based and representative ecumenical body. Two years later (1936) The Christian Council of South Africa: an Association of Churches and Missionary Societies for the Extension of the Kingdom of God was founded. Two Dutch Reformed 
Church (DRC) ministers, William Nicol (chairman) and John du Toit (secretary), were elected as the first office bearers.

The road towards unity and ecumenical cooperation was not easy. During the Second World War (1938-1945) political differences left their mark on the Christian Council. In 1940 the Anglican Church left the body, and in 1941 the DRC followed suit. When a number of German missionaries were interned because of the war, the work of the council virtually came to a standstill (Gerdener, 1958:175).

After the war the Christian council slowly resumed its activities. The Anglicans rejoined the council and the DRC, from time to time, cooperated in the programmes. Funding the work of the council in its Johannesburg office, as well as its numerous programmes across the country, was a perennial problem and the response of the other protestant churches to partake in die work of the Christian Council, often lukewarm. Nevertheless, concluded Elfriede Strassberger in her history of the ecumenical movement in South Africa, the council "as far as its organisational set-up and program of action were concerned, until 1960, [was] the most truly expressive ecumenical council in South Africa" (Strassberger, 1974:239).

In December 1960, in the aftermath of the Sharpville massacre, the World Council of Churches (WCC) invited all its member churches in South Africa to a consultation to be held in Cottesloe (Johannesburg) to discuss the churches' role in the looming racial crisis in the country. At the consultation a decision was made to found a body representing all the local member churches of the WCC. The Cottesloe resolutions, highly critical of the South African government's apartheid polity, created a storm in the country - and in the months that followed the DRC withdrew its membership of the WCC. All of this impacted negatively on the Christian Council and its plans to reach out to other churches in South Africa (Geldenhuys, 1982:107).

\subsection{The South African Council of Churches: crises and opportunities}

In 1967 an Anglican clergyman, Bill Burnett, was elected general secretary of the Christian Council. He was a man of vision and courage, and under his leadership the council not only decided to adopt a new name, The South African Council of Churches, but also a new constitution and a new agenda for the body (1968). In the past, the main emphasis of the council revolved mainly around mission and evangelism. Now the challenge was to accept a more prophetic role, to concentrate on the social, economic and political 
questions that the churches in apartheid South Africa had to face. It was a hazardous road to take, and not everybody was enthralled by the new direction. The Church of the Nazarene, the Baptist Church as well as the Salvation Army, cut their ties with the SACC. And when the SACC published its bold Message to the people of South Africa (1968) shock waves were sent through the country. The Message with its strong anti-apartheid content was sent to 600 pastors and clergy in South Africa, urging them to stand up for justice and reconciliation in the country. "To whom does your highest loyalty, your strongest commitment belong?", the Message asked. "Is it to a subsection of mankind, an ethnic group, a human tradition, a political idea; or to Christ?" (SACC, 1968:3).

Under the leadership of consecutive general secretaries, the SACC's programmes expanded. John Rees (1970-1973) as well as John Thorne (1977) did much to strengthen the council's administration and its budget, and to encourage and empower black leadership in the SACC. In 1978 Desmond Tutu became the first black South African to be elected general secretary. In 1985 Beyers Naude, after having served house arrest for many years, was appointed to succeed Tutu. Two years later Frank Chikane was elected to the SACC's highest office. The 1970s and 1980s were difficult years. Politically and socio-economically South Africa was on the brink. The SACC had to find its way through the storms. The views expressed by the SACC and its leaders, as well as the protest actions the SACC initiated or joined, evoked serious critisism from the side of the Afrikaans churches, as well as other evangelical denominations. The South African government was angered by the SACC's actions and threatened to ban the council for being an "affected organisation". The Kairos document, signed by 50 prominent church leaders, and accepted as an official statement of the SACC was the last straw. The government embarked on a series of actions to inhibit the SACC and to curtail its witness. The Eloff commission was appointed to enquire into the finances of the SACC. The offices of the SACC were the target of numerous raids by the security police. Members of staff, among them Frank Chikane, were detained and often tortured. Eventually on 31 August 1988, Khotso House, the SACC's head office in Johannesburg, was severely damaged by a bomb, planted by the South African Police (SACC, 1997:3 ff.).

With the unbanning of the African National Congress and other liberation movements in 1990, as well as the dawning of a new democratic order in South Africa in 1994, the fortunes of the SACC 
changed dramatically. Frank Chikane was invited to serve as secretary of the newly elected president Nelson Mandela's cabinet. His mantle fell on Ms Brigalia Bam, the first woman to be appointed to lead the SACC. She and her successors, Charity Majisa, Molefe Tsele and Eddie Makue had the task to guide the SACC to rediscover and to fulfil its obligations in the new South Africa, with all its opportunities and challenges.

\section{The influence of Calvinism on the South African Council of Churches}

This then, in short, is the story of the SACC. The following question is: To what extent did Calvinism - the churches of reformed and presbyterian extraction belonging to the council - influence the story? That these churches had an impact on the South African community goes without saying. The history of the Afrikaans churches - the Nederduitse Gereformeerde Kerk, the Nederduitse Hervormde Kerk in Africa and the Gereformeerde Kerke van Suid-Afrika - dates back to 1652 when Jan van Riebeeck founded the first European settlement in the Cape. Early in the nineteenth century other churches belonging to the Calvinist-reformed tradition found their way to South Africa: presbyterians as well as congregationalists. All of these churches were active in the field of missions, resulting in the founding of numerous black reformed or presbyterian congregations, which contributed significantly to developments in the ecumenical community in South Africa through the years.

Much has been written on Calvin's reception in South Africa (Vosloo, 2009:5 ff.). However, the question remains: How strong was the impact of the reformed-presbyterian-congregationalist churches on the SACC? I want to answer the question by firstly pointing to the role a number of leaders, coming from a Calvinist background, played in the history of the SACC. Secondly, I want to trace the influence of a number of Calvinist principles on the ecumenical agenda in South Africa.

\subsection{Calvinists in leadership positions in the SACC}

Through history, Calvinists were regarded to be people who take their divine calling seriously. Elected by God to serve Him both in the church, as well as in the wider community, they are called to act as ambassadors of his Kingdom in all walks of life. It comes as no surprise that among the "shakers and the doers" in the South African community, Calvinists are to be found. The story of the SACC includes the stories of many men and women of Calvinist extract who, 
each in their own way, played a significant role in the SACC's assemblies, administration and programmes, as well as in shaping the council's theology. They were not the only ones. The influence of Calvinism is more multi-faceted than the role of these church leaders. In the limited space allowed for an article, the following list will have to suffice.

It has already been noted that, in the early years with the establishment of the Christian Council, two Dutch Reformed Church ministers, William Nicol and John du Toit, took the lead. The same happened in the life of the SACC. Since the 1970s, four Calvinists were elected president of the council: John Thorne (United Congregational Church), Sam Buti (DRC in Africa), Russel Botman (Uniting Reformed Church) and Tinyiko Maluleke (United Presbyterian Church). Three of seven general secretaries came from the Calvinist community: John Thorne (United Congregational Church), Beyers Naué (Dutch Reformed Church in Africa) and Edwin Makue (Uniting Reformed Church). In the ranks of theologians who served the SACC in many ways - drafting documents, contributing to the assemblies, leading theological discussions, mapping the way the SACC had to follow - the names of numerous Calvinists appear, among them Douglas Bax, Roelf Meyer, Ben Engelbrecht, Allan Boesak, John de Gruchy, Thakatso Mofokeng, David Bosch, Jaap Durand, Dirkie Smit, Johan Botha and Tinyiko Maluleke.

\subsection{Calvinist principles}

It would be totally wrong to surmise that only the Calvinists shaped the programmes and principles of the SACC. Many other denominations and leaders from different traditions contributed to the thinking and the actions of the SACC. To ignore the Calvinist input in the process would be equally wrong. In many instances the views and the principles of the Genevan reformer were reflected in the life of the SACC.

During the current Calvin celebrations, much attention was given to the heritage of Calvin, and the theological principles he held most dear.

According to Callie Coetzee in an article recently published in Christelike kernensiklopedie (Coetzee, 2008:157), Calvinism rests upon two pillars. Firstly, Calvinism may be seen as a theology founded upon the Bible as the Word of God, speaking to us with the authority of God himself. Secondly, Calvinism provides a very specific view of life. The Christian message is not only, or primarily, about the 
salvation of mankind, it is primarily about the authority of God in all spheres of life. Calvin wrote extensively on the relationship between the church and the government, the church and the economy, et cetera. Christians, according to Calvin, have a divine calling to accept and to proclaim the Lordship of Christ wherever they find themselves, be it at home, in the church, or in the wider community. (For a similar but more comprehensive definition of Calvinism, cf. Cross, 1957:220 ff.). Both these pillars come into play when the influence of Calvinism on the SACC is evaluated. Calvinist theology as well as the Calvinist view of life are reflected in the following paragraphs.

How important are Calvin's views - the main tenets of Calvinism - to us today, in South Africa as well as in the rest of the world? In an official publication celebrating the legacy of John Calvin, co-edited by Lukas Vischer and Setri Nyomi, a number of issues raised by Calvin that are still relevant to Christians at the beginning of the third millennium, are noted: to manifest the gift of communion, covenanting for justice, and addressing violence and destruction in the world (Vischer \& Nyomi, 2008). Turning to the South African situation, especially paging through the history of the SACC, I would like to propose that the fingerprints of Calvin may be recognised in its programmes and statements, in at least five different areas.

\subsubsection{The quest for unity}

The SACC's continued search for unity among the Christian churches in South Africa and its endeavors to provide a platform where Christians from many denominations can meet, is directly congruent with Calvin's message. Vischer and Nyomi (2008:12) remind us that, for Calvin, the unity of the church was a key concern. The fourth part of Calvin's Institutes of the Christian religion was devoted to this theme. In his commentaries on the books of the Bible, the theme of unity is also often underlined:

The frequent repetition of the word one is emphatic. Christ cannot be divided. Faith cannot be rent. There are not various baptisms, but one which is common to all. God cannot cease to be one, and unchangeable. It cannot but be our duty to cherish holy unity, which is bound by so many ties. Faith, and baptism, and God the Father, and Christ, ought to unite us, so as almost to become one man. (Calvin, 1948:4.5:269.)

Although John Calvin broke ranks with the Roman Catholic Church, he lamented the disunity of the church throughout his ministry, encouraging the Christians of his day to seek unity at all times. Being 
the man who committed himself "to cross ten oceans" to further the unity of the church, he urged his counterparts to work towards unity because the beliefs and practices that bound them together were far more important than the differences that kept them apart (cf. Durand, 1961:47 ff.; Crafford \& Gous, 1993:75 ff.).

Leaders from many denominations in South Africa shared the SACC's commitment to ecumenism and worked hard to further the cause of unity among the many churches in the land. It is, however, equally evident that some of the most outspoken champions of church unity in the SACC hailed from the ranks of the reformed and presbyterian churches, and by doing that, saw themselves walking in the footsteps of Calvin. Beyers Naudé in many of his editorials in Pro Veritate as well as John de Gruchy and David Bosch (1998) in their writings, are but three examples of Calvinists in the SACC family who, from the heart of their theological tradition, never tired of calling the South African churches to unity. The unequivocal call for unity in the statements and messages of the SACC through the years would have carried the blessing of John Calvin.

\subsubsection{The concern for mission and evangelism}

The history of the SACC started with the establishment of the General Missions Council and continued later, with the founding of the Christian Council of South Africa. The strong commitment of both organisations was the proclamation of the gospel of Christ to all men and women in the land, as well as beyond the borders of South Africa. In this process the representatives of the reformed and presbyterian churches in the SACC acted according to their centuries-old Calvinist missionary tradition.

How strong was the Reformer's missionary commitment? is a question often asked. One of the most outspoken critics of the protestant churches in this regard, was Cardinal Bellarmine who, in the wake of the Reformation accused the protestant churches of a lack of missionary interest and endeavor, adding that this clearly indicated that they were false churches. Taking their cue from Bellarmine, it has become customary for many to blame Lutherans as well as Calvinists for their perceived lack of missionary enthusiasm (Neill, 1966:221). This accusation, David Bosch had shown convincingly, is not fair - especially not of John Calvin and his successors who did have a clear vision for mission (Bosch, 1998:239 ff.). With Calvin's enthusiastic blessing reformed missionaries left for Brazil. And in the seventeenth century when Dutch ships criss-crossed the oceans, 
Calvinist missionaries accompanied them to bring the gospel to the nations.

It was Dutch Reformed clergy in the Cape at the end of the eighteenth century who founded the South African Mission Society, inviting congregational missionaries from the London Missionary Society, to help spread the gospel of Christ among the indigenous people in Southern Africa. The interest in mission and evangelism that the SACC had later shown, especially in the 1960s and 1970s, was therefore partially rooted in the commitment of the Calvinist member churches to honour Jesus' imperative: "You will be my witnesses" (Acts 1:8). The National Conference on Mission and Evangelism (Durban, 1973) was hailed by all - also by the reformed, presbyterian and congregational delegates - as an important and groundbreaking event on the ecumenical calendar (De Gruchy, 2006:152).

\subsubsection{Covenanting for justice: unmasking the theology and the practice of apartheid}

The call for social justice is a recurring theme in Calvin's writings, especially in his sermons and in the actions he undertook in Geneva (Vischer \& Nyomi, 2008:28). In his footsteps, during the centuries, numerous reformed leaders dared to confront injustice in society, challenging the powers of their time, often at a very high cost to themselves. In South Africa, in the later half of the twentieth century, standing for justice invariably meant confronting the issue of racism, unmasking the heresy of apartheid theology, and fighting for the rights of the oppressed and marginalised.

Ironically, in the past apartheid was defended by many as a typical Calvinist solution to the racial problems of South Africa. In 1948 when the National Party won the general election on their apartheid ticket, it was with the support and encouragement of the Dutch Reformed Church, which fashioned its views on Afrikaner Nationalism and self-determination on its interpretation of Calvinism (VosIoo, 2009:3 ff.). At a Calvin Conference held at Stellenbosch (2009) Allan Boesak spoke of his first experience with apartheid theology in the 1960s, the time of Sharpville and of the infamous Treason Trial of anti-apartheid activists:

It was ... the first time I heard of "Boere-Calvinisme"... espoused by Dr. Vorster and the vast majority of the DRC, of how apartheid was a true reflection of the Reformed belief in sola Scriptura, a biblical and Christian policy, and a 'consistent Calvinism' that did not lead to 'integration and the intermingling 
of blood'. I now also came to know that apartheid was not only the purist expression of Reformed faith, but precisely the obedience to the 'law of love', and the 'only solution to South Africa's race problem'. (Boesak, 2009:1 ff.)

But Boesak also recalled his meetings at the time with Beyers Naudé and other reformed theologians who, from a sincere Calvinist position, questioned the policy of apartheid.

Beyers Naudé introduced me to the whole array of apartheid theology designers and defenders, but importantly also to the dissidents, and more crucially, held up the challenge to discover for myself the authentic Calvinist tradition he was convinced the white Afrikaans churches had lost. (Boesak, 2009:2.)

Numerous Calvinist theologians and church leaders - together with a growing number of young black and reformed theologians - stood behind Naudé and Boesak in their condemnation of the sin and the heresy of apartheid. They were convinced that "apartheid had become the grave of the dignity and the credibility of the Reformed tradition" (Boesak, 1984:86). The good name of Calvinism needed to be restored! In helping the SACC to develop its views on racism and on the need for justice, as well as by drafting strong anti-apartheid statements, the panel of reformed theologians who aligned themselves with Naudé and Boesak - Bax, De Gruchy, Bosch, Maluleke and their colleagues - acted in accordance with their deepest Calvinist beliefs.

\subsubsection{Prophetic witness}

The church is called to be a prophet, to take a stand against inhumanity and injustice whenever and wherever it occurs. The strong stance that Calvin took in this regard, sometimes at a heavy cost to himself, served as an inspiration to many - also to reformed Christians in South Africa. Boesak in his Stellenbosch address referred to this:

We discovered how much at the heart of the Reformed tradition were the issues of compassionate justice, God's choice for the poor, the oppressed and the wronged, the protection of the weak and the needy, the equitable distribution of wealth, power, privileges and responsibilities ...

We heard John Calvin as he insisted that "the name "neighbour" extends indiscriminately to every person, because the whole human race is united by a sacred bond of fellowship ... To make any person our neighbour it is enough that they be 
human', and we claimed it for ourselves in the struggle against all forms of racism and exclusion of all kinds.

We heard John Calvin and for us, racism in society and in the church became a sin, an assault upon the dignity of God, a denial of the reconciling work of Jesus Christ, a heresy and a blasphemy.

We heard Calvin's fiery sermons against wealth, selfishness, and the single-minded pursuit of profits. (Boesak, 2009:10 ff.)

In the centuries that followed, reformed Christians continued to be inspired by Calvin's strong stance. In an address at the Christian Social Congress (1891) the Dutch theologian and politician Abraham Kuyper reiterated Calvin's sentiments:

When rich and poor stand opposed to each other, Jesus never takes place with the wealthier, but always with the poorer. He is born in a stable; and while foxes have holes and birds have nests, the Son of Man has nowhere to lay his head ... Both the Christ, and also just as much as his disciples after him as the prophets before him, invariably took sides against those who were powerful and living in luxury, and for the suffering and the oppressed. (Kuyper quoted by Boesak, 2009:12.)

During the latter decades of the previous century, the South African Council of Churches published a series of strong statements calling the South African churches and the government, as well as the wider public to task. The message to the people (1968) was followed by the Study project on Christianity in an apartheid society (Sprocas, 1972), the Resolution on conscientious objection (1974), the Resolution on non co-operation with the state (1979), the Declaration of apartheid as a heresy (1982), the Call to prayer to end unjust rule (1985), the Lusaka statement, in support of the liberation movement (1987), the Call for disinvestment (1988), and the Kairos document (1989). Some of these statements were very controversial and fuelled the fires of criticism against the SACC. At times it caused division within the ranks of the SACC itself. However, the fact that the SACC in standing up for justice and for truth, specifically siding with the poor and the marginalised, acted within the finest tradition of the Genevan reformation, goes without saying (De Gruchy, 1991:78-83).

\subsubsection{Confronting the government}

That the SACC and the South African government landed on a collision course, was inevitable. The above-mentioned statements from 
the SACC irritated and angered the apartheid government, who thought of itself as a "Christian government" that deserved obedience and loyalty of all citizens, especially of the churches. Some of the activities and programmes of the council, above all the SACC's support of the World Council of Churches' Programme to combat racism, added fuel to the fire.

Should Christians stand up against the government - even rebel against the authority of the state? was the question uppermost in the minds of many South African Christians. At a first glance it would seem that Calvin's advice - with his strong emphasis on Paul's injunctions in Romans 13 to obey the state as "the servant of God", who "does not bear the sword in vain" - would be in the negative. That is, however, only half of the story: Calvin also demanded of the state to rule justly. A just and well-regulated government will be distinguished for maintaining the rights of the poor and the afflicted (Boesak, 2009:12). The time may come, Calvin conceded, that tyranny by the state should be resisted. With reference to Isaiah 14:7-8, he stated:

Here he (Isaiah) shows how greatly tyrants are hated by the whole world. When they are dead or ruined, all men break forth into joy ... The Heavenly Judge cannot endure tyrants, who are abhorred by the whole world. (Calvin, 1935:14.7-8:439 ff.)

The clash between the South African government and the SACC was severe. Strong actions were taken against the SACC and its leadership in the 1970s and 1980s (see 1.2 above). When meetings between the two adversaries did take place, hard words from both sides were spoken. On one occasion Desmond Tutu led a SACC delegation to meet with Alwyn Schlebusch, the then Minister of Law and Order. In exasperation, Tutu did not mince his words:

Mr Minister, we must remind you that you are not God. You are just a man. And one day your name shall merely be a faint scribble on the pages of history, while the name of Jesus Christ, the Lord of the Church, shall live forever ..." (SACC, 1997:2).

During these difficult times the SACC leadership - and especially those from the ranks of the reformed and presbyterian churches took their cue from Calvin and from the reformed tradition. When Allan Boesak called the SACC churches to massive civil disobedience and for direct involvement of the churches in the struggle for liberation (1979) it was according to his own testimony "informed by the radical Calvinism, I had come to know and embrace" (Boesak, 
1984:32 ff.). The same, according to Boesak, applied to Beyers Naudé and his colleagues:

So when Beyers Naudé sides with the poor and the oppressed in South Africa, he is the true representative of the Reformed tradition, not those who banned him and sought to bring dishonor to his name.

When the Presbyterian Church of Southern Africa decided to challenge the government on as fundamental an issue as Christian marriage, it is closer to the Reformed tradition than are those who vindicate an unjust law.

It is not the perpetrators of injustice, but those who resist it who are the true representatives of the Reformed tradition. (Boesak, 1984:94.)

\section{New challenges in South Africa}

In 1994 the South African scene changed dramatically. For the first time in the history of the country, South Africans from all racial groups went to the polls. Nelson Mandela, fresh out of prison, became the first president of a truly democratic South Africa. For the SACC and its member churches the arrival of the new dispensation brought great joy and jubilation. Special services to celebrate and to give thanks to God were held. Many of the views espoused by the council, many of the battles fought, were vindicated. A number of SACC stalwarts were invited to join the new government, to help build the community we all longed for. Among them were two general secretaries. Frank Chikane left his office in Khotso House to relocate to the Union Buildings in Pretoria to become the secretary of Mandela's cabinet. Some years later Brigalia Bam accepted an appointment as chair of the South African Electoral Commission.

It did not take long, however, for reality to set in. Despite all the good that the new South Africa brought us, we are not out of the woods not by a far stretch! In spite of the work of the Truth and Reconciliation Commission in the 1990s, South Africa is still a deeply divided community, in dire need of reconciliation and healing on many levels. The chasm between rich and poor is as deep as always. Millions still live in abject circumstances in shacks and in informal settlements, without work and without resources. The scourge of HIV and AIDS and other diseases is with us. Xenophobia simmers under the surface, threatening to erupt at any given time. Stories of crime and violence, of poor service delivery, of corruption and greed and racism are carried daily on the front pages of the 
newspapers. Above all an ecological disaster threatens our very existence. Many South Africans seem to have lost hope - many have lost their faith.

All of the above have a great impact on the SACC. In order to fulfil its role today as it did in the past, the SACC will have to rediscover its calling and to rethink its agenda. In confronting the new challenges, the SACC may once again call on its reformed members to contribute to solving the problems of the day. The reformed community has much to offer. The Accra declaration of the World Alliance of Reformed Churches offers new and exhilarating initiatives to address the issues of poverty and economic injustice in the world. And following in the footsteps of John Calvin, who already in the sixteenth century called upon Christians to respect the sanctity of life and to protect the environment in which we live (Vischer \& Nyomi, 2008:42 ff.), Calvinist theologians may be able to help develop a viable and sustainable ecological strategy, that would benefit us all and help conserve the world for our children and grandchildren. Above all, from our reformed tradition we need answers on how to present Jesus Christ in such a way in a secular society, that men and women will recognise him as their Lord and Saviour.

\section{Conclusion}

In the opening paragraph of this article, reference was made to Tertullian's question: "What is there in common between Athens and Jerusalem?" What has Greek culture and philosophy to do with the gospel of Jesus Christ? Tertullian's answer - although many of his contemporaries differed from him - was an emphatic: "Nothing!" In answering my question: "What is there in common between Geneva and the South African Council of Churches?", it seems that there will be a general agreement: "Everything!" In discussing the contribution of reformed theology on the thinking of the SACC and of the role of Calvinist leaders in shaping the actions and policies of the council, it is evident that Geneva and Johannesburg, through the years, have supported and enriched one another in many ways. They may continue to do this in future. If that be the case, the final verdict in true Calvinist style should be Soli Deo gloria!

\section{List of references}

BETTENSON, H. 1950. Documents of the Christian church. London: Oxford University Press.

BOESAK, A. 1984. Black and reformed: apartheid, liberation and the Calvinist tradition. Maryknoll: Orbis. 
BOESAK, A. 2009. At the heart of it all: perspectives on the struggle for the relevance of the reformed tradition in South Africa. Address at the Calvin Conference, Stellenbosch, 30 August-2 September 2009.

BOSCH, D.J. 1998. Transforming mission. Maryknoll: Orbis.

CALVIN, J. s.a. Institutes of the Christian religion. Vol. 1 \& 2. Ed. by J.T. McNeill. Philadelphia: Westminster Press.

CALVIN, J. 1935. Commentary on the book of the prophet Isaiah. Vol. 1. Trans. by W. Pringle. Grand Rapids: Eerdmans.

CALVIN, J. 1948. Commentaries on the epistles to the Galatians and Ephesians. Trans. by W. Pringle. Grand Rapids: Eerdmans.

COETZEE, C.F.C. Calvinisme. (In Gaum, F. \& Boesak, A. Christelike kernensiklopedie. Wellington: Lux Verbi.BM. p. 157.)

CRAFFORD, D. \& GOUS, G. 1993. Een liggaam, baie lede: die kerk se ekumeniese roeping wêreldwyd en in Suid-Afrika. Pretoria: Verba Vitae.

CROSS, F.L. 1957. The Oxford dictionary of the Christian church. Oxford: Oxford University Press.

DE GRUCHY, J. 1991. Liberating reformed theology. Grand Rapids: Eerdmans.

DE GRUCHY, J. 2006. Being human. London: SCM.

DE GRUCHY, J. 2009. John Calvin: Christian humanist, evangelical reformer. Wellington: Lux Verbi.BM.

DURAND, J.J.F. 1961. Una sancta catholica in sendingperspektief. Amsterdam: Ten Have.

GAUM, F. \& BOESAK, A., reds. 2008. Christelike kernensiklopedie. Wellington: Lux Verbi.BM.

GELDENHUYS, F.E. O'B. 1982. In die stroomversnelling: vyftig jaar van die NG Kerk. Kaapstad: Tafelberg.

GERDENER, G.B.A. 1958. Recent developments in the South African mission field. Cape Town: NG Kerkuitgewers.

KOOPMAN, N. 2009. Calvin and public holiness in Africa: address at the Calvin Conference, Stellenbosch 2009.

NEILL, S.C. 1966. A history of Christian missions. Harmondsworth: Penguin.

SACC

see SOUTH AFRICAN COUNCIL OF CHURCHES

SMIT, D. 2009. On Calvin's reception in South Africa: address at the Calvin Conference, Stellenbosch 2009.

SOUTH AFRICAN COUNCIL OF CHURCHES. 1968. A message to the people of South Africa. Johannesburg: SACC.

SOUTH AFRICAN COUNCIL OF CHURCHES. 1997. Submission to the South African Truth and Reconciliation Commission. East London: TRC.

STRASSBERGER, E. 1974. Ecumenism in South Africa 1936-1960. Johannesburg: SACC.

VISCHER, L. \& NYOMI, S. 2008. The legacy of John Calvin. Geneva: WARC, John Knox Center.

VOSLOO, R. 2009. Remembering John Calvin in South Africa today? Address at the Calvin Conference, Stellenbosch 2009. 


\section{Key concepts:}

Calvinism

reformed theology

South Africa, churches

South African Council of Churches

\section{Kernbegrippe:}

\section{Calvinisme}

gereformeerde teologie

Suid-Afrika, kerke

Suid-Afrikaanse Raad van Kerke 